\title{
EPICS: Meeting Outcomes with Multidisciplinary Student Teams
}

\author{
William Oakes, Maeve Drummond, Carla Zoltowski \\ EPICS Program, Purdue University, West Lafayette, IN, USA \\ oakes@purdue.edu,maeve@purdue.edu,.cbz@purdue.edu
}

\begin{abstract}
Engineering Projects in Community Service - EPICS - is a service-learning program that was developed nearly twenty years ago at Purdue University. Under this program, undergraduate students in multidisciplinary teams earn academic credit for longterm projects that solve technology-based problems for local or global community service organizations. The EPICS model has been implemented at 23 universities in North American and on other continents. With its emphasis on the start-to-finish design of significant projects that will be deployed by the community customers, EPICS addresses many of the program outcomes mandated by ABET and the CEAB and, more broadly, to meet the Washington Accord graduate attributes. This paper describes the curricular and assessment procedures and documentation that have been developed to enhance and evaluate the students' abilities to meet outcomes including functioning on multidisciplinary teams; communicate effectively; and understand the impact of engineering solutions in a global and societal context.
\end{abstract}

Keywords: Accreditation, ABET, multidisciplinary design, service-learning, teams

\section{INTRODUCTION}

Engineering has seen significant changes over the last few decades. The pace of technological innovation has accelerated requiring graduates to know more and to be able to adapt to emerging technologies. Many of these technologies span traditional technical areas requiring professionals to work across disciplines. As the global economy has developed, engineers are required to be able to work across cultures as well as disciplines.

Thriving in this environment requires a strong and broad technical foundation as well as a diverse set of professional skills that include the ability to work with multidisciplinary and multi-cultural teams, an awareness of cultural, environmental and ethical issues and a strong ability to communicate through writing and speaking. Global competition puts pressure on corporations to onboard graduates more rapidly. Industry is asking for engineering programs to prepare graduates to be able to make an impact early in their careers.

The engineering accreditation bodies have adapted their criteria for engineering institutions to address these needs. In the U.S., ABET introduced EC 2000 that is outcomes based and covers the broad range of technical and professional skills [1]. The Canadian Engineering Accreditation Board (CEAB) identified attributes of graduates to address similar needs [2].

A challenge for engineering educators is that many of the outcomes sought by the accreditation bodies are difficult to achieve in traditional courses. Pedagogies such as community engagement can help meet these outcomes. There are a growing number of successful models of engineering-based community engagement in the U.S., Canada and globally. This paper will describe the EPICS Program as an example of a successful program that has met accreditation criteria in multiple disciplines using community engagement. The program will be described as well as the assessment process used to document the outcomes for accreditation.

\section{ENGINEERING ACCREDITATION FOR GLOBAL LEADERSHIP IN THE 21ST CENTURY}

Accreditation bodies internationally have recognized the need to ensure that engineering graduates have a strong technical foundation as well as the broad set of professional skills to contribute and lead in today's global economy. The Washington Accord brought together accreditation bodies to recognize engineering degrees across international boundaries [3]. Two of the original signatories of the accord, the U.S. and Canada have established criteria that reflect the broad skills needed for leadership in the 21 st century $[1,2]$.

In the U.S., ABET is the accrediting body for all engineering and technology programs. It adopted criteria for student outcomes that all engineering programs should meet. Engineering Criteria (EC) 2000 has focused attention on the design process and on many of the "realworld" skills that students will need to embark on 
successful engineering careers. ABET has defined general criteria for baccalaureate level programs that include seven criteria. These are Criterion 1. Students; Criterion 2. Program Educational Objectives; Criterion 3. Student Outcomes; Criterion 4. Continuous Improvement; Criterion 5. Curriculum; Criterion 6. Faculty; and Criterion 7. Facilities. [1]

We are particularly interested in Criterion 3 - Student Outcomes- that contains 11 outcomes. Every accredited program must document how students achieve these outcomes. Programs are allowed to add to the outcomes but these 11 must be met by all programs. The outcomes are listed and known by the letters a thru $\mathrm{k}$ and include:

(a) an ability to apply knowledge of mathematics, science, and engineering

(b) an ability to design and conduct experiments, as well as to analyze and interpret data

(c) an ability to design a system, component, or process to meet desired needs within realistic constraints such as economic, environmental, social, political, ethical, health and safety, manufacturability, and sustainability

(d) an ability to function on multidisciplinary teams

(e) an ability to identify, formulate, and solve engineering problems

(f) an understanding of professional and ethical responsibility

(g) an ability to communicate effectively

(h) the broad education necessary to understand the impact of engineering solutions in a global, economic, environmental, and societal context

(i) a recognition of the need for, and an ability to engage in life-long learning

(j) a knowledge of contemporary issues

(k) an ability to use the techniques, skills, and modern engineering tools necessary for engineering practice.

In Canada, the criteria for student learning, as defined by the Canadian Engineering Accreditation Board $(\mathrm{CEAB})$, are similar and described in terms of graduate attributes [2]. There are 12 graduate attributes and each institution must demonstrate that the graduates of a program possesses these attributes. The attributes are to be interpreted in the context of candidates at the time of graduation and it is recognized that graduates will continue to build on the foundations that their engineering education has provided. The attributes are identified by numbers from 3.1.1 to 3.1.12 and include:

3.1.1 A knowledge base for engineering: Demonstrated competence in university level mathematics, natural sciences, engineering fundamentals, and specialized engineering knowledge appropriate to the program.
3.1.2 Problem analysis: An ability to use appropriate knowledge and skills to identify, formulate, analyze, and solve complex engineering problems in order to reach substantiated conclusions.

3.1.3 Investigation: An ability to conduct investigations of complex problems by methods that include appropriate experiments, analysis and interpretation of data, and synthesis of information in order to reach valid conclusions.

3.1.4 Design: An ability to design solutions for complex, open-ended engineering problems and to design systems, components or processes that meet specified needs with appropriate attention to health and safety risks, applicable standards, and economic, environmental, cultural and societal considerations.

3.1.5 Use of engineering tools: An ability to create, select, apply, adapt, and extend appropriate techniques, resources, and modern engineering tools to a range of engineering activities, from simple to complex, with an understanding of the associated limitations.

3.1.6 Individual and team work: An ability to work effectively as a member and leader in teams, preferably in a multi-disciplinary setting.

3.1.7 Communication skills: An ability to communicate complex engineering concepts within the profession and with society at large. Such ability includes reading, writing, speaking and listening, and the ability to comprehend and write effective reports and design documentation, and to give and effectively respond to clear instructions.

3.1.8 Professionalism: An understanding of the roles and responsibilities of the professional engineer in society, especially the primary role of protection of the public and the public interest.

3.1.9 Impact of engineering on society and the environment: An ability to analyze social and environmental aspects of engineering activities. Such ability includes an understanding of the interactions that engineering has with the economic, social, health, safety, legal, and cultural aspects of society, the uncertainties in the prediction of such interactions; and the concepts of sustainable design and development and environmental stewardship.

3.1.10 Ethics and equity: An ability to apply professional ethics, accountability, and equity.

3.1.11 Economics and project management: An ability to appropriately incorporate economics and business practices including project, risk, and change management into the practice of engineering and to understand their limitations.

3.1.12 Life-long learning: An ability to identify and to address their own educational needs in a changing world in ways sufficient to maintain their competence and to allow them to contribute to the advancement of knowledge. 
Many of these outcomes and attributes called out by ABET and the CEAB are difficult to achieve in traditional courses. Community engagement experiences, such as the EPICS Program, provide rich learning experiences for these diverse attributes. The authentic design challenges within communities also offer opportunities for crossdisciplinary teams and learning. The EPICS .Program at Purdue University engages students from many disciplines on engineering-centered, community-driven design projects.

\section{THE EPICS PROGRAM}

The EPICS Program at Purdue University is a multidisciplinary, vertically-integrated, student-led, service-learning design course. The program began at Purdue University in 1995 because of feedback from industry that students were not adequately prepared for the transition into professional careers. The founders, Professors Leah Jamieson and Edward Coyle recognized the opportunities that partnering with community organizations offered. They began with 40 senior-level students from Electrical and Computer Engineering working on five project teams [4]. After the first semester, the course began attracting students from other majors as well as younger students. The program has continued to grow and be integrated into the institution. EPICS is used as a substitute for a variety of courses from many disciplines. In many cases, students take EPICS as an elective, including technical and disciplinary electives. There are currently 32 divisions with over 400 students each semester (and over 800 for an academic year). Each division is broken down into project teams that are typically 4-6 students. Students enrolled come from more than 70 majors that represent all of the colleges within the university. EPICS students can participate multiple semesters; teams include first-year through senior students, and typically have a mix of returning and new students on the team. The learning outcomes of the course are listed in Table 1. Students take on different roles, such as project manager, design lead, and project partner liaison, and the students and team are mentored by advisors (faculty, professional staff from Purdue and local industry) [5].

EPICS decouples the student learning, academic calendar, and the project timelines. The timelines are decoupled, so that projects can extend beyond one academic term. This allows projects to be scoped to meet the needs of the community partner, not the requirements of the academic timeline. It allows for iteration within the design process as problems and improvements are identified. In addition, students can participate for multiple semesters. To encourage this, the EPICS courses are one or two credit hours, whereas a typical course
EPICS is used to substitute for (e.g. technical elective) is three credit hours. These returning students often take on increased leadership responsibilities each semester and provide continuity to the projects. These aspects together allow us to facilitate long-term relationships with our community partners and provide the long-term support they need.

EPICS has been recognized by the NAE with the Bernard M. Gordon Prize for Innovation in Engineering and Technology Education (2004) [6]; as an NAE exemplar of programs in "Infusing Real World Experiences into Engineering Education (2012); by the NSF Corporate Foundation Alliance as an Exemplar Program (2002); the Association of Public and Land Grant Universities as an Exemplar of Engagement, by Campus Compact with the Thomas Ehrlich Award, and by the American Society for Engineering Education with the Chester Carlson Award for Innovation in Engineering Education (1997 and 2012). In 2013, IEEE recognized EPICS as a signature program.

EPICS has been disseminated to 23 other universities and colleges. While each program shares core values or characteristics with all other EPICS programs there is considerable variation in each of the programs, based on how long they have been in place as well as institutional culture [7]. EPICS has also been adapted for high school and middle school with more than 50 schools in 11 states within the U.S. having EPICS programs with an additional $30+$ abroad through a partnership with IEEE $[8,9]$.

Examples of projects and a full description of the Purdue University EPICS teams can be found at https://engineering.purdue.edu/EPICS/Projects/Teams. Examples of teams at other EPICS Universities, or colleges can be seen on the EPICS University website at: https://engineering.purdue.edu/EPICSU/Projects

\section{ACCREDITATION AND EPICS}

Assessment of student outcomes is a significant challenge for EPICS in general given the variability in students who are first-year to senior and from about 70 majors with different expertise and experiences to bring to the project. And since we decouple the project timelines from the academic calendar, students may start the semester with a new project or work on a project that was not completed in the previous semester. Therefore, we use an assessment process that is modeled after the performance appraisal systems used in the corporate world to individualize each student's assessment. The first step in the assessment process is for students to establish their goals and expectations for the semester in consultation with the faculty member who oversees that section of EPICS, and formative evaluations are completed throughout the semester for all students. 
However, the students using EPICS to meet their senior (fourth year) or capstone design course requirements (currently approved for Computer, Electrical, Environmental and Ecological and Multidisciplinary Engineering) are expected to meet all eight of the learning outcomes with at least 3 credits of EPICS taken over 2 or more semesters. These eight learning outcomes can be mapped to the accreditation attributes from ABET (referred to by letters a-k) or the CEAB criteria (numbers 3.1.1-3.1.12) as shown in Table 1.

Table 1: Learning Outcomes, ABET and CEAB

\begin{tabular}{|c|c|c|}
\hline Learning Outcomes & ABET & $\begin{array}{l}\text { CEAB } \\
\text { Graduate } \\
\text { Outcomes } \\
\end{array}$ \\
\hline $\begin{array}{l}\text { i. applies material from } \\
\text { their discipline to the } \\
\text { design of community-based } \\
\text { projects }\end{array}$ & $\begin{array}{l}\mathrm{a}, \mathrm{b}, \mathrm{c}, \\
\mathrm{d}, \mathrm{i}, \mathrm{k}\end{array}$ & $\begin{array}{l}3.1 .1,3.1 .2, \\
3.1 ., 3,3.1 .4, \\
3.1 .5, \\
3.1 .7,3.1 .9\end{array}$ \\
\hline $\begin{array}{l}\text { ii. demonstrates an } \\
\text { understanding of design as } \\
\text { a start-to-finish process }\end{array}$ & $\begin{array}{l}\mathrm{b}, \mathrm{d}, \mathrm{e}, \\
\mathrm{k}\end{array}$ & $\begin{array}{l}3.1 .4,3.1 .5 \\
3.1 .11\end{array}$ \\
\hline $\begin{array}{l}\text { iii. an ability to identify } \\
\text { and acquire new } \\
\text { knowledge as a part of the } \\
\text { problem-solving/design } \\
\text { process }\end{array}$ & $\begin{array}{l}a, b, c \\
d, h\end{array}$ & $\begin{array}{l}3.1 .2,3.1 .3, \\
3.1 .4,3.1 .11\end{array}$ \\
\hline $\begin{array}{l}\text { iv. demonstrates an } \\
\text { awareness of the customer } \\
\text { in engineering design }\end{array}$ & $\begin{array}{l}\mathrm{d}, \mathrm{f}, \mathrm{g}, \\
\mathrm{i}, \mathrm{j}, \mathrm{k}\end{array}$ & $\begin{array}{l}3.1 .4,3.1 .6 \\
3.1 .7,3.1 .8 \\
3.1 .9,3.1 .10 \\
\end{array}$ \\
\hline $\begin{array}{l}\text { v. demonstrates an ability } \\
\text { to function on } \\
\text { multidisciplinary teams and } \\
\text { an appreciation for the } \\
\text { contributions from } \\
\text { individuals from other } \\
\text { disciplines }\end{array}$ & $\mathrm{e}, \mathrm{g}, \mathrm{i}$ & $\begin{array}{l}3.1 .6,3.1 .7 \\
3.1 .8\end{array}$ \\
\hline $\begin{array}{l}\text { vi. demonstrates an ability } \\
\text { to communicate effectively } \\
\text { with audiences with } \\
\text { widely-varying } \\
\text { backgrounds }\end{array}$ & $\mathrm{e}, \mathrm{g}, \mathrm{i}$ & $\begin{array}{l}3.1 .7,3 . .1 .8, \\
3.1 .10\end{array}$ \\
\hline $\begin{array}{l}\text { vii. demonstrates an } \\
\text { awareness of professional } \\
\text { ethics and responsibility }\end{array}$ & $\mathrm{f}, \mathrm{i}, \mathrm{j}$ & $3.1 .9,3.1 .10$ \\
\hline $\begin{array}{l}\text { viii. demonstrates an } \\
\text { appreciation of the role } \\
\text { that their discipline can } \\
\text { play in social contexts }\end{array}$ & $\begin{array}{l}\mathrm{f}, \mathrm{g}, \mathrm{h}, \\
\mathrm{i}, \mathrm{j}\end{array}$ & $\begin{array}{l}3.1 .7,3.1 .8, \\
3.1 .9,3.1 .10 \\
3.1 .12\end{array}$ \\
\hline
\end{tabular}

While EPICS has the potential to meet a broad set of outcomes and attributes and provide a variety of experiences, we have established a process to ensure that the senior design students' specific experiences meet the senior design requirements. For example, a student may be the team leader of a team of 20 or more students with four projects being developed simultaneously for their community partner. This student would have to devote a considerable amount of time to administrative and leadership issues. While this is incredibly valuable and will serve the student well after graduation, the student's experience may not meet the technical aspects of the senior design outcomes.

To address this concern, procedures have been implemented both to manage and assess the senior design students. The first step in the process is identification of the students. Students who are using EPICS for capstone must register for their own course number (EPCS 411 or 412). They meet with the other students but the course number flags them as a senior design student. The team leaders, advisors and teaching assistants are made aware that there are specific criteria for these students that must be taken into account as they are assigned to projects and roles for that project. A specific document, the Project Proposal, is used to certify whether the project is appropriate for the senior design student. Because of the customer-driven, multidisciplinary nature of the program, some projects may not be appropriate for capstone credit in their respective major. For example, a team may be working on a mechanical engineering project in which there are minimal Electrical design elements would not be appropriate for the Electrical Engineering student. While these projects may be well suited for a student seeking a technical elective experience that broadens his or her technical scope, they are not suited for the senior design students. The Project Proposal (Appendix A) is an individual report to ensure that the project and the student's specific role are appropriate. It also helps the student to plan how they will meet all of the outcomes.

Because students in EPICS complete different activities over two semesters to fulfill the senior design requirements, a tracking form has been developed to ensure the outcomes are met and is shown in Appendix B. This form contains a matrix with each outcome and places for the students to indicate how they have met each and where the artifacts reside that document their achievement. The Outcomes form is updated by students throughout their senior design experiences and reviewed periodically by the advisor and teaching assistant during the semester. A rubric is used in the evaluation of each outcome. An example of the rubric is shown in Appendix C. In addition to certifying outcomes, the assessment process is used to flag potential problems and to redirect a student's effort if it appears that s/he will not satisfy the requirements. The final approval by the advisor certifies that the student has satisfied the senior design outcomes based on the rubric.

The outcomes matrix is also used to provide grades for the senior design students. Since they are assessed based 
on achieving the outcomes, the same criteria in the senior design rubric is used in assigning the grade. This integrates the outcomes or attributes into the grading process. It does mean that the senior design students have slightly different grading criteria than the other students on their teams but the criteria are complementary to the other students.

Students document their work to achieve these outcomes in many ways. These include:

- Project Deliverables: The team's delivered projects are evidence of the work accomplished, and of the design process.

- Design Notebooks or Blogs: Individual documentation is required for all EPICS students. Most students use physical notebooks that are evaluated three times per semester (weeks 4, 8, 15) but electronic means, such as blogs, are allowed too.

- Design Reviewers: Design reviews are scheduled twice per semester for every team. Reviewers include alumni, corporate partners as well as other faculty. Design reviews are a way to engage faculty and professionals with the expertise most appropriate for the project.

- Design Documentation: Every project has a report that describes the design and has contributions from all of the students who have worked on that project.

- Peer Evaluations: Completed electronically by students at mid-semester and at the end of the semester. Students evaluate the performance of all team members and themselves along key dimensions.

The final document that is used to manage the senior design process is the Project Description (Appendix D), which is a project level document used to describe how individuals on a given project team have met the outcomes. This document is common among the senior design courses within a given department.

The revisions and history of the three documents used in senior design are managed using Microsoft SharePoint Server software. The SharePoint server provides a means to limit access to documents and to track who has revised documents. At the beginning of the process, students are able to download and edit templates of the document, then store their individual copies of the documents on the SharePoint server to be reviewed by the advisors and teaching assistants for monitoring and assessment. Although the Project Proposal, Outcome Matrix, and Project Description are approved by the advisor as part of the grading process, each semester these documents are reviewed by EPICS administrators and representatives from the discipline for continual improvement. Feedback from those reviews identify if changes are needed to the processes or structures. In addition, it is communicated back to the advisors and teaching assistants.

An important aspect in the senior design process is the training and educating of the senior design students themselves. All senior design students review a module at the beginning of the semester where the requirements and procedures are laid out and their responsibility in the process. The students are made aware of the required outcomes and means to meet these outcomes and are made an explicit part of the process. They are empowered to take the responsibility to see their own process through to certification.

\section{CONCLUSION}

Meeting the diverse set of accreditation attributes can be a challenge in traditional engineering courses. The EPICS Program is a proven model that uses community engagement within an academic program to meet outcomes and attributes as part of an accreditation process. The learning and assessment processes used by EPICS have successfully been used within Electrical and Computer Engineering for three accreditation cycles, Multidisciplinary twice and Environmental and Ecological Engineering once. During each review, the personalized assessment portfolios that EPICS produces for each student have been cited as a positive component of the college. ABET recognized EPICS by inviting the directors to conduct a workshop for faculty during the annual ABET Symposium in 2014 and has collaborated on curriculum reform proposals with EPICS.

Involving students in community engagement alone does not ensure attainment of the accreditation attributes. Students are matched with projects that have the potential to meet their disciplinary requirements. All projects do not fit all disciplines, nor are all roles within a project appropriate. If an appropriate project and role cannot be identified within the current team, students are moved to a team and project to match their requirements. The curricular structure and its emphasis on reflection and documentation generates the artifacts needed to document attribute attainment. Students are made a full partner in the process with responsibilities for documenting their achievement of the attributes. Providing the rubrics to the students allows them to understand and meet the criteria.

As confirmed by the accreditation process, community engagement programs like EPICS provide a compelling way for students to learn design and prepare for the professional world. It must not be overlooked that another strong feature of community engagement is the resulting benefit to non-profit organizations and the people they serve. 
Proc. 2015 Canadian Engineering Education Association (CEEA15) Conf.

\section{References}

[1] http://www.abet.org/eac-criteria-2015-2016/

[2] Canadian attributes

https://www.engineerscanada.ca/sites/default/files/2014_accr editation_criteria_and_procedures_v06.pdf pp. 13-14. Accessed 4/19/2015

[3] http://www.ieagreements.org/Washington-Accord/

[4] Zoltowski, C. B., and Oakes, W.C., "Learning by Doing: Reflections of the EPICS Program", Special Issue: University Engineering Programs That Impact Communities: Critical Analyses and Reflection, International Journal for Service-Learning in Engineering, 2014, pp. 1-32.

[5] Coyle, Edward J, Leah H. Jamieson, and Larry S. Sommers, "EPICS: A Model for Integrating Service-Learning into the Engineering Curriculum", Michigan Journal of Community Service Learning, Vol. 4, Fall 1997, pp. 81-89.
[6] Coyle, Edward J., Jamieson, Leah H., Oakes, William C , "Integrating Engineering Education and Community Service: Themes for the Future of Engineering Education”, Journal of Engineering Education, Vol. 95, No. 1, January 2006, pp. 7-11.

[7] Oakes, W., Zoltowski, C. and Drummond, M, "Dissemination Of Community Engagement In Engineering And Computing", Proceedings of the 2014 Frontiers in Education Conference, Madrid, Spain, October 2014.

[8] Nation, Sarah, Oakes, William, Bailey, Lowell, Heinzen, Jill, "Conversion of Collegiate EPICS to a K-12 Program", Proceedings of the Frontiers in Education Conference, Indianapolis, IN, October 2005

[9] Thompson , Michael, Pamela Turner and William Oakes, "Teaching Engineering In High School Using ServiceLearning: The EPICS Model", Proceedings of the 2008 ASEE Annual Conference, Pittsburgh, PA, June 2008 


\section{APPENDIX A: Purdue EPICS Senior Design Project Proposal Report}

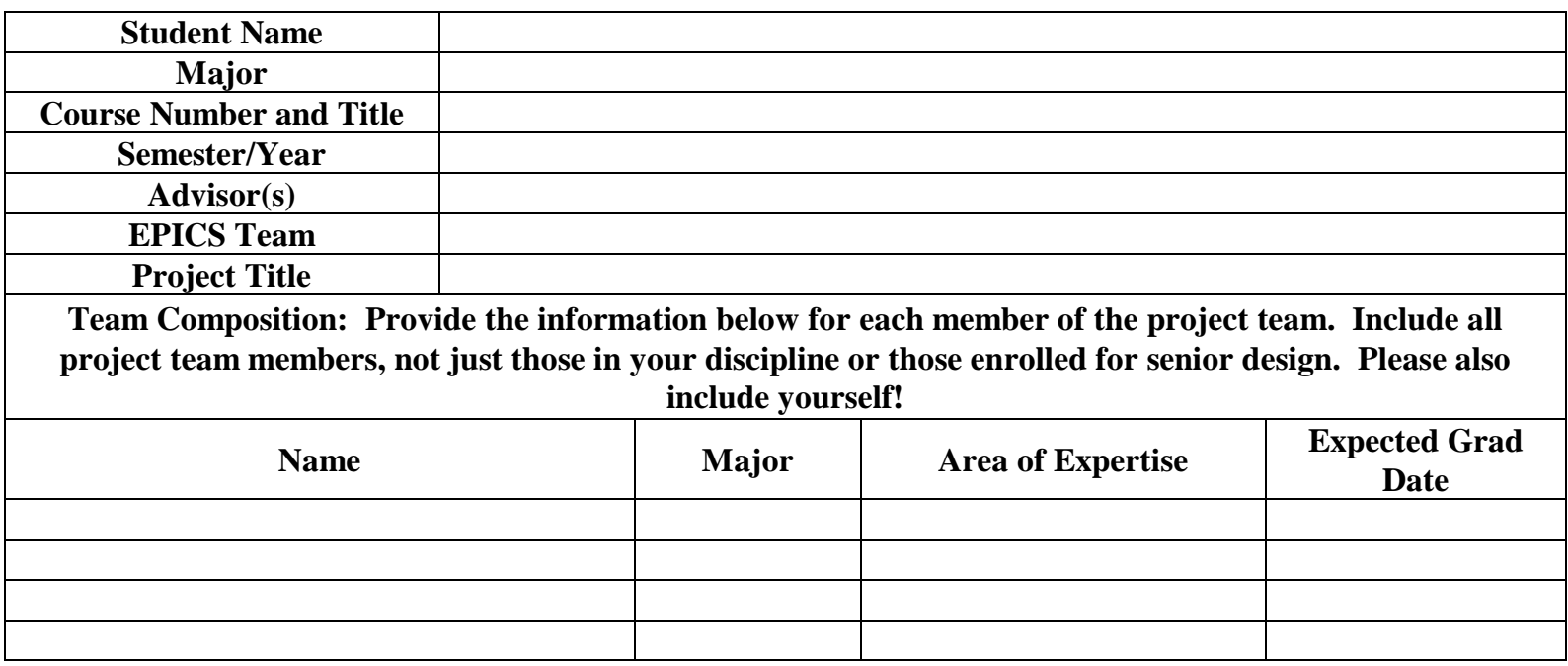

Project and Task Description: Provide a brief (one or two page) technical description of the design project and your specific tasks, as outlined below:

(a) Provide a summary of the project, including a description of the customer and their requirements, the purpose, specifications, and a summary of the approach.

(b) Describe the specific role and tasks that you individually will be completing as part of the design of the project. What specific deliverables will you produce?

(c) Discuss in detail the specific approach that will be used to complete your portion of the design.

(d) Describe the phases of the design process that will be incorporated during your two semesters of senior design and what work will be accomplished during those phases.

Outcome Matrix: Describe your plan to demonstrate each of the outcomes below

\begin{tabular}{|l|l|}
\hline Outcomes: & Plan for demonstrating outcome: \\
\hline $\begin{array}{l}\text { i. applies material from their discipline to the design of community- } \\
\text { based projects }\end{array}$ & \\
\hline ii. demonstrates an understanding of design as a start-to-finish process & \\
\hline $\begin{array}{l}\text { iii. an ability to identify and acquire new knowledge as a part of the } \\
\text { problem-solving/design process }\end{array}$ & \\
\hline iv. demonstrates an awareness of the customer in engineering design & \\
\hline $\begin{array}{l}\text { v. demonstrates an ability to function on multidisciplinary teams and an } \\
\text { appreciation for the contributions from individuals from other } \\
\text { disciplines }\end{array}$ & \\
\hline $\begin{array}{l}\text { vi. demonstrates an ability to communicate effectively with audiences } \\
\text { with widely-varying backgrounds }\end{array}$ & \\
\hline vii. demonstrates an awareness of professional ethics and responsibility & \\
\hline $\begin{array}{l}\text { viii. demonstrates an appreciation of the role that their discipline can } \\
\text { play in social contexts }\end{array}$ & \\
\hline
\end{tabular}


APPENDIX B: EPICS Senior Design Outcomes Matrix

\begin{tabular}{|c|c|c|c|c|}
\hline \multicolumn{5}{|c|}{ EPICS Senior Design Outcomes Matrix } \\
\hline Student's Name: & & \multicolumn{3}{|c|}{ Semesters Recorded: } \\
\hline Team: & Project: & & & \\
\hline Outcomes: & $\begin{array}{l}\text { Describe how the student's realization of the } \\
\text { outcome is documented }\end{array}$ & \begin{tabular}{|l|} 
Student \\
Initials \& \\
Date:
\end{tabular} & $\begin{array}{l}\text { TA Initials } \\
\text { \& Date: }\end{array}$ & \begin{tabular}{|l|} 
Advisor \\
Assessment* \\
\& Initials, Date:
\end{tabular} \\
\hline \multicolumn{5}{|l|}{$\begin{array}{l}\text { i. applies material from their } \\
\text { discipline to the design of } \\
\text { community-based projects }\end{array}$} \\
\hline \multicolumn{5}{|l|}{$\begin{array}{l}\text { ii. demonstrates an } \\
\text { understanding of design as a } \\
\text { start-to-finish process }\end{array}$} \\
\hline \multicolumn{5}{|l|}{$\begin{array}{l}\text { iii. an ability to identify and } \\
\text { acquire new knowledge as a } \\
\text { part of the problem- } \\
\text { solving/design process }\end{array}$} \\
\hline \multicolumn{5}{|l|}{$\begin{array}{l}\text { iv. demonstrates an } \\
\text { awareness of the customer in } \\
\text { engineering design }\end{array}$} \\
\hline \multicolumn{5}{|l|}{$\begin{array}{l}\text { function on multidisciplinary } \\
\text { teams and an appreciation for } \\
\text { the contributions from } \\
\text { individuals from other } \\
\text { disciplines }\end{array}$} \\
\hline \multicolumn{5}{|l|}{$\begin{array}{l}\text { vi. demonstrates an ability to } \\
\text { communicate effectively with } \\
\text { audiences with widely-varying } \\
\text { backgrounds }\end{array}$} \\
\hline \multicolumn{5}{|l|}{$\begin{array}{l}\text { vii. demonstrates an } \\
\text { awareness of professional } \\
\text { ethics and responsibility }\end{array}$} \\
\hline \multicolumn{5}{|l|}{$\begin{array}{l}\text { viii. demonstrates an } \\
\text { appreciation of the role that } \\
\text { their discipline can play in } \\
\text { social contexts }\end{array}$} \\
\hline $\begin{array}{l}\text { Names and Locations of } \\
\text { completed Design Records } \\
\text { (minimum of } 2 \text { required) }\end{array}$ & & & & \\
\hline
\end{tabular}

${ }^{*}$ See the Senior Design Outcomes Rubric 


\section{APPENDIX C: EPICS Senior Design Outcomes Rubric Example}

\begin{tabular}{|c|c|c|c|c|}
\hline Outcomes: & Unacceptable $(\mathrm{F})$ & Marginal (D/C) & Adequate (B/C) & Excellent (A) \\
\hline $\begin{array}{l}\text { i. applies } \\
\text { material } \\
\text { from their } \\
\text { discipline } \\
\text { to the } \\
\text { design of } \\
\text { community- } \\
\text { based } \\
\text { projects }\end{array}$ & $\begin{array}{l}\text { Cannot identify } \\
\text { relevant principles } \\
\text { or develop models } \\
\text { to apply to their } \\
\text { design. Not able } \\
\text { to predict or } \\
\text { understand } \\
\text { parameter effects } \\
\text { on the design. } \\
\text { Does not } \\
\text { understand } \\
\text { phenomena and } \\
\text { cannot explain. } \\
\text { Unable to transfer } \\
\text { knowledge from } \\
\text { their disciplinary } \\
\text { courses to new } \\
\text { situations. }\end{array}$ & $\begin{array}{l}\text { Have difficulty deciding } \\
\text { what principles to use, but } \\
\text { may develop a close to } \\
\text { correct model to apply to } \\
\text { their design. Has some } \\
\text { difficulty solving } \\
\text { equations; frequent errors, } \\
\text { problems often partially } \\
\text { solved. Difficulty } \\
\text { predicting parameter } \\
\text { effects on the design. } \\
\text { Some understanding of } \\
\text { disciplinary concepts, but } \\
\text { has to resort to jargon to } \\
\text { explain. If the situation is } \\
\text { not too novel, } \\
\text { occasionally sees } \\
\text { application of knowledge } \\
\& \text { may apply correctly. }\end{array}$ & $\begin{array}{l}\text { May include extraneous } \\
\text { principles, but ultimately } \\
\text { finds correct ones and } \\
\text { develops model(s) to } \\
\text { apply to their designs. } \\
\text { Answers often correct, } \\
\text { but may have minor } \\
\text { errors. Uses non-optimal } \\
\text { strategies. Usually } \\
\text { predicts impacts of } \\
\text { parameters correctly and } \\
\text { explains effects. } \\
\text { Reasonably good } \\
\text { understanding of } \\
\text { concepts. Can often } \\
\text { explain, but may resort to } \\
\text { jargon. Usually sees how } \\
\text { to apply knowledge to } \\
\text { new situations, may need } \\
\text { help. }\end{array}$ & $\begin{array}{l}\text { Readily identifies the } \\
\text { relevant principles \& } \\
\text { develops elegant } \\
\text { models to apply to } \\
\text { their design. } \\
\text { Consistently solves } \\
\text { problems elegantly \& } \\
\text { correctly. Excellent } \\
\text { at prediction and } \\
\text { provides clear } \\
\text { explanations of } \\
\text { effects. Excellent } \\
\text { understanding and } \\
\text { clear explanations of } \\
\text { disciplinary concepts. } \\
\text { Sees the fundamental } \\
\text { nature of novel } \\
\text { problems and } \\
\text { correctly applies } \\
\text { knowledge. }\end{array}$ \\
\hline $\begin{array}{l}\text { ii. } \\
\text { demonstrat } \\
\text { es an } \\
\text { understand } \\
\text { ing of } \\
\text { design as a } \\
\text { start-to- } \\
\text { finish } \\
\text { process }\end{array}$ & $\begin{array}{l}\text { Unable to demonstrate } \\
\text { understanding of the } \\
\text { whole design process. } \\
\text { No ability to apply the } \\
\text { design process to their } \\
\text { current project. } \\
\text { Problem not } \\
\text { understood. Did not } \\
\text { consider alternatives } \\
\text { when making design } \\
\text { decisions. No } \\
\text { appropriate iterations } \\
\text { in the design process } \\
\text { considered. No } \\
\text { review of prior work. } \\
\text { Sound design } \\
\text { principles are not used } \\
\text { or used incorrectly. } \\
\text { No cost estimates. Not } \\
\text { organized, did not } \\
\text { meet deadlines and } \\
\text { milestones. Design } \\
\text { does not meet partner } \\
\text { requirements and } \\
\text { constraints. No } \\
\text { evaluation } \\
\text { of design done or } \\
\text { done incorrectly }\end{array}$ & $\begin{array}{l}\text { Demonstrates some } \\
\text { understanding of each } \\
\text { phase of the design } \\
\text { process. Can apply } \\
\text { the phases to their } \\
\text { current project only } \\
\text { with assistance. } \\
\text { Insufficient review of } \\
\text { prior work. Few if } \\
\text { any alternative } \\
\text { approaches explored } \\
\text { for design decisions. } \\
\text { Serious deficiencies } \\
\text { in iterating through } \\
\text { the design process. } \\
\text { Reasonable cost } \\
\text { estimates. Used } \\
\text { design principles but } \\
\text { with serious errors. } \\
\text { Routinely missed } \\
\text { deadlines. Design } \\
\text { barely meets } \\
\text { requirements and } \\
\text { constraints. } \\
\text { Evaluation of design } \\
\text { incomplete or } \\
\text { partially erroneous. }\end{array}$ & $\begin{array}{l}\text { Demonstrates adequate } \\
\text { understanding of the } \\
\text { whole design process. } \\
\text { Applies phases of the } \\
\text { design process to their } \\
\text { current project. } \\
\text { Adequate review of prior } \\
\text { work. Identified some } \\
\text { alternative approaches } \\
\text { before finalizing design } \\
\text { decisions. Design } \\
\text { iterations initiated } \\
\text { occasionally or done with } \\
\text { prompting. Provides } \\
\text { reasonable cost } \\
\text { estimates. Design } \\
\text { principles appropriately } \\
\text { applied to achieve } \\
\text { reasonable solution. } \\
\text { Missed few deadlines. } \\
\text { Design meets partner } \\
\text { requirements \& } \\
\text { constraints with } \\
\text { moderately effective use } \\
\text { of resources. } \\
\text { Sound evaluation of } \\
\text { design supports } \\
\text { conclusions. }\end{array}$ & $\begin{array}{l}\text { Demonstrates } \\
\text { excellent } \\
\text { understanding of the } \\
\text { design process and } \\
\text { effectively applies } \\
\text { active phases to the } \\
\text { current project. } \\
\text { Complete review of } \\
\text { prior work. } \\
\text { Reviewed reasonable } \\
\text { alternatives before } \\
\text { finalizing design } \\
\text { decisions. Initiated } \\
\text { appropriate design } \\
\text { iterations. Excellent } \\
\text { cost estimates. } \\
\text { Design principles } \\
\text { applied appropriately } \\
\text { and without error. } \\
\text { Effectively } \\
\text { organized, met all } \\
\text { deadlines. Design } \\
\text { meets or exceeds } \\
\text { partner requirement } \\
\& \text { constraints. } \\
\text { Insightful evaluation } \\
\text { supports conclusions } \\
\& \text { recommendations }\end{array}$ \\
\hline
\end{tabular}


APPENDIX D: Purdue EPICS Senior Design Project Description

\begin{tabular}{|c|c|c|c|c|c|}
\hline \multicolumn{6}{|l|}{ Course Number and Title } \\
\hline \multicolumn{6}{|l|}{ Semester/Year } \\
\hline \multicolumn{6}{|l|}{ Advisor(s) } \\
\hline \multicolumn{6}{|l|}{ EPICS Team } \\
\hline \multicolumn{6}{|l|}{ Project Title } \\
\hline \multicolumn{6}{|c|}{ Senior Design Students: } \\
\hline Name & Major & Area of Expertise & $\begin{array}{l}\text { Expected } \\
\text { Grad } \\
\text { Date }\end{array}$ & $\begin{array}{l}\text { On team } \\
1^{\text {st }} \text { sem. of } \\
\text { senior } \\
\text { design? }\end{array}$ & $\begin{array}{l}\text { On team } \\
2^{\text {nd }} \text { sem. of } \\
\text { senior } \\
\text { design? }\end{array}$ \\
\hline & & & & & \\
\hline & & & & & \\
\hline \multicolumn{6}{|c|}{$\begin{array}{l}\text { Other Team Members: } \\
\text { (Names of all project team members of the project team that have participated during the two semesters of } \\
\text { the senior design students' experience on the team.) }\end{array}$} \\
\hline Name & Major & Area of Expertise & $\begin{array}{l}\text { Expected } \\
\text { Grad } \\
\text { Date }\end{array}$ & $\begin{array}{l}\text { On team } \\
1^{\text {st }} \text { sem. of } \\
\text { senior } \\
\text { design? }\end{array}$ & $\begin{array}{c}\text { On team } \\
2^{\text {nd }} \text { sem. of } \\
\text { senior } \\
\text { design? }\end{array}$ \\
\hline & & & & & \\
\hline & & & & & \\
\hline & & & & & \\
\hline & & & & & \\
\hline
\end{tabular}

Project Description: Provide a brief (one or two page) technical description of the design project, as outlined below:

(e) Summary of the project, including customer, purpose, specifications, and a summary of the approach.

(f) Description of how the project built upon knowledge and skills acquired in earlier ECE/CS/MDE coursework (include course numbers).

(g) Description of what new technical knowledge and skills, if any, were acquired in doing the project;

(h) Description of how the engineering design process is incorporated into the project. Reference must be made to most of the following fundamental steps of the design process: establishment of objectives and criteria, synthesis, analysis, construction, testing, and evaluation.

(i) Summary of how realistic design constraints are being incorporated into the project (consideration of most of the following is required: economic, environmental, ethical, health \& safety, social, political, sustainability, and manufacturability constraints).

(j) Description of the multidisciplinary nature of the project.

(k) Description of project deliverables and their final status. 